\title{
PENGARUH MODEL PEMBELAJARAN INKUIRI BERBASIS PICTORIAL RIDDLE DAN BERPIKIR KRITIS TERHADAP HASIL BELAJAR FISIKA SISWA SMAN 17 MEDAN T.P 2015/2016
}

\author{
Masrida Gultom dan Jurubahasa Sinuraya \\ Jurusan Fisika FMIPA Universitas Negeri Medan \\ masrida.gultom@yahoo.com
}

\begin{abstract}
ABSTRAK
Penelitian ini bertujuan untuk mengetahui: 1) perbedaan hasil belajar fisika siswa menggunakan model pembelajaran inkuiri berbasis pictorial riddle dengan pembelajaran konvensional, 2) perbedaan hasil belajar siswa berpikir kritis tinggi dengan berpikir kritis rendah, 3) interaksi antara model pembelajaran inkuiri berbasis pictorial riddle dengan berpikir kritis terhadap hasil belajar fisika siswa. Populasi penelitian adalah seluruh siswa kelas XI IPA SMAN 17 Medan T.P 2015/2016. Sampel penelitian yaitu kelas XI IPA-4 dan XI IPA-5. Teknik pengambilan sampel secara cluster random sampling dengan metode quasi experiment. Berdasarkan variabel penelitian terdiri dari dua tipe data yang dikumpulkan, yaitu: 1) data berpikir kritis dan 2) data hasil belajar fisika siswa. Data berpikir kritis siswa dan data hasil belajar siswa diperoleh dari pertanyaan tes yang tersedia. Teknik analisis data menggunakan ANAVA dua jalur dengan taraf signifikan $\alpha=0.05$. Hasil penelitian menunjukkan bahwa: 1) terdapat perbedaan hasil belajar fisika siswa yang mengunakan model pembelajaran inkuiri berbasis pictorial riddle dengan pembelajaran konvensional, 2) terdapat perbedaan hasil belajar fisika siswa yang berpikir kritis tinggi dengan berpikir kritis rendah, 3) terdapat interaksi antara model pembelajaran inkuiri berbasis pictorial riddle dan berpikir kritis terhadap hasil belajar fisika siswa.
\end{abstract}

Kata Kunci: model pembelajaran inkuiri, pictorial riddle, berpikir kritis, hasil belajar

\section{Abstract}

This research objectives to know: 1) the difference in physics learning outcomes of student using inquiry learning model based pictorial riddle with learning conventional; 2) the difference in physics learning outcomes of students who have high critical thinking with students who have low critical thinking; and 3) the interaction between thinking inquiry learning model based pictorial riddle and critical toward physics learning outcomes. Population in this research is all of students of SMAN 17 Medan class XI Science Academic Year 2015/2016. Samples in this research are class XI Science - 4 and XI Science - 5. Samples technique is cluster random sampling with quasi experiment methods. According to research variables there are two types of data collected in this research, namely: 1) critical thinking data of students and 2) physics learning outcomes data of students. Critical thinking data of students and data student learning outcomes collected by providing test questions to students. Technique of analyzing data by using ANAVA two ways with the significant level of $\alpha=0.05$. The result of research shown that: 1) there is difference in physics learning outcomes of students using inquiry learning model based pictorial riddle with learning conventional; 2) there is difference in physics learning outcomes of students who have high thinking critical with students who have low critical thinking; and 3) there is interaction between inquiry learning model based pictorial riddle and critical thinking toward physics learning outcomes.

Key Words: inquiry learning model, pictorial riddle, critical thinking, outcomes learning 


\section{PENDAHULUAN}

Sasaran semua cabang sains, terutama fisika, pada umumnya adalah mencoba menemukan keteraturan di dalam observasi terhadap dunia di sekeliling kita. Sains adalah sebuah aktivitas kreatif dalam banyak aspeknya menyerupai aktivitasaktivitas lain yang dilahirkan manusia. Seorang saintis harus memutuskan halhal apa yang relevan dalam observasi dan eksperimen yang dijalankannya terutama dalam proses pembelajaran (Giancoli, 2014). Telah menjadi fenomena umum bahwa sains, terutama fisika dianggap sebagai pelajaran yang sulit dan tidak disukai, diketahui dari rata-rata nilai mata pelajaran fisika yang cenderung rendah. Selain banyak konsep yang abstrak, untuk memahami fisika diperlukan kemampuan berpikir tingkat tinggi serta kemampuan matematika sebagai alat bantunya. Selain itu, istilah-istilah yang digunakan dalam bidang fisika seringkali dimaknai secara khusus yang berbeda dengan istilah yang sama dalam kehidupan sehari-hari.

Masalah lain yang dihadapi dunia pendidikan kita adalah lemahnya proses pembelajaran (Sanjaya, 2010). Setiap proses pembelajaran, anak kurang didorong untuk menggunakan kemampuan berpikir. Proses pembelajaran di dalam kelas diarahkan kepada kemampuan anak untuk menghapal informasi; otak anak dipaksa untuk mengingat dan menimbun berbagai informasi tanpa dituntut untuk memahami informasi yang diingatnya itu untuk menghubungkannya dengan kehidupan sehari-hari. Akibatnya adalah ketika anak didik kita lulus sekolah, mereka pintar secara teoritis, tetapi mereka miskin aplikasi. Kenyataan ini berlaku untuk semua mata pelajaran.

Ada empat masalah pokok yang penting yang menjadikan pedoman dalam keberhasilan pelaksanaan kegiatan belajar mengajar (Ngalimun, 2012). Masalah pokoknya adalah: pertama, memilih cara pendekatan belajar yang dianggap paling tepat dan efektif mencapai sasaran. Kedua, memilih dan menetapkan prosedur, metode dan teknik belajar mengajar yang dianggap paling tepat dan efektif. Ketiga, menetapkan norma-norma dan kriteria keberhasilan sehingga guru mempunyai pegangan yang dapat dijadikan ukuran untuk menilai sampai sejauh mana keberhasilan tugas-tugas yang dilakukannya. Keempat, spesifikasi dan kualifikasi perubahan tingkah laku yang bagaimana yang hendak dicapai dalam kegiatan pembelajaran yang dilakukan itu.

Studi pendahuluan yang dilaksanakan di SMA N 17 Medan membuahkan hasil yaitu persentasi hasil belajar fisika siswa di atas Kriteria Ketuntasan Minimal (KKM) pada ujian akhir semester masih mencapai $40 \%$ dalam setiap kelas. Model pembelajaran yang digunakan guru adalah pembelajaran konvensional. Pembelajaran konvensional yang dimaksud adalah model pembelajaran yang selama ini digunakan oleh guru. Guru memang sudah mengenal model pembelajaran dan bahkan sudah menerapkannya dalam pembelajaran, akan tetapi, guru masih belum konsisten mengenai penerapan setiap fase dalam model pembelajaran. Penggunaan model pembelajaran ini tentunya sudah dinilai baik, namun alangkah baiknya jika dilaksanakan secara konsisten. Selanjutnya, berdasarkan angket yang 
disebarkan kepada siswa menghasilkan bahwa $75 \%$ siswa setuju setiap awal pembelajaran guru mengawali pembelajaran dengan pemberian beberapa pertanyaan yang berkaitan dengan materi pembelajaran. Setelah itu, $70 \%$ siswa setuju mereka bisa menghasilkan jawaban dari proses berpikir mereka sendiri, yang kemudian bisa dibuktikan dengan teori. Artinya, siswa rata-rata menginginkan belajar dari fakta ke teori.

Berdasarkan indikator-indikator permasalahan yang dijelaskan di atas, dibutuhkan solusi pembelajaran yang tepat dan efektif. Salah satu solusi yang tepat tersebut adalah dengan penerapan model pembelajaran efektif yang mampu meningkatkan keterampilan proses siswa. Salah satu model pembelajaran yang efektif diterapkan adalah model pembelajaran inkuiri berbasis pictorial riddle.

Model pembelajaran inkuiri diterapkan dengan cara mempertemukan para siswa dengan keadaan atau masalah yang sedikit membingungkan mereka, kemudian dengan bertanya dan melakukan eksperimentasi, mereka diajak untuk membangun dan menguji gagasangagasan (Joyce, dkk., 2011). Guru yang efektif selalu percaya diri bahwa mereka dapat membuat suatu perbedaan dan bahwa perbedaan tersebut dibuat dengan cara menyesuaikan strategi atau perangkat pembelajaran mereka dengan kondisi siswa saat ini, kemudian guru mempelajari pola belajar siswa dengan cermat dan membuat lingkungan belajar menjadi nyaman dan menyenangkan untuk mempercepat peningkatan hasil belajar siswa. Ada tiga hal yang menjadi ciri dari inkuiri (Sanjaya, 2010). Pertama, inkuiri menekankan kepada aktivitas siswa secara maksimal untuk mencari dan menemukan, artinya inkuiri menempatkan siswa sebagai subjek belajar. Kedua, seluruh aktivitas yang dilakukan siswa diarahkan untuk mencari dan menemukan jawaban sendiri dari sesuatu yang dipertanyakan, sehingga diharapkan dapat menumbuhkan sikap percaya diri. Inkuiri menempatkan guru bukan sebagai sumber belajar, akan tetapi sebagai fasilitator dan motivator belajar siswa. Aktivitas pembelajaran biasanya dilakukan melalui proses tanya jawab antara guru dan siswa. Oleh sebab itu kemampuan guru dalam menggunakan teknik bertanya merupakan syarat utama dalam melakukan inkuri. Siswa yang dapat menggunakan kemampuan berpikirnya berarti dapat menguasai pelajaran.

Pictorial riddle merupakan metode yang mempresentasikan informasi ilmiah dalam bentuk poster atau gambar yang disajikan di depan kelas atau digunakan langsung dalam diskusi. Pictorial riddle ini dapat mengembankan motivasi dan minat peserta didik dalam diskusi kelompok kecil atau besar yang dapat digunakan untuk meningkatkan hasil belajar peserta didik (Hamruni, 2012). Materi pelajaran fisika banyak dituangkan dalam bentuk gambar untuk mendapatkan penjelasan yang rinci. Hubungan antara benda-benda dan tindakan dalam gambar dengan bahasa siswa memungkinkan mereka melakukan peralihan secara ilmiah dari bahasa tutur menjadi bahasa tulis. Siswa juga menghubungkan sesuatu dalam gambar dengan kata dan kemudian melihat kata itu muncul dalam cetakan atau tulisan. 
Materi fisika seperti fluida dinamis, memerlukan gambar untuk memperjelas pemahaman siswa sehingga pada waktu guru memberikan pelajaran siswa langsung bisa menangkap materi yang disampaikan oleh guru. Selain mendengarkan mereka langsung bisa menghubungkannya dengan gambar. Seperti yang dapat disimak dari proses pembelajaran, tujuan utama pembelajaran melalui inkuiri adalah menolong siswa untuk dapat mengembangkan disiplin intelektual dan hasil belajar dengan memberikan pertanyaan-pertanyaan dan mendapatkan jawaban atas dasar ingin tahu mereka.

Dewey (dalam Fisher, 2009) mendefinisikan berpikir kritis atau berpikir reflektif sebagai pertimbangan yang aktif, persistent (terus-menerus), dan teliti mengenai sebuah keyakinan atau bentuk pengetahuan yang diterima begitu saja dipandang dari sudut alasan-alasan yang mendukungnya dan kesimpulan-kesimpulan lanjutan yang menjadi kecenderungannya.

Peneliti sebelumnya Mahmudah, dkk., (2014) berdasarkan hasil penelitian didapatkan ada pengaruh kemampuan berpikir kritis tinggi dan rendah terhadap prestasi belajar kognitif, afektif dan psikomotorik. Peneliti Sirait, dkk., (2012) yang juga menggunakan model inkuiri, dihasilkan adanya pengaruh menggunakan model pembelajaran inkuiry training terhadap hasil belajar siswa. Kristianingsih, dkk., (2010) berdasarkan hasil penelitian, model pembelajaran inkuiri berbasis pictorial riddle dapat meningkatkan hasil belajar siswa. Rangkuti, (2010) berdasarkan hasil penelitian didapatkan ada perbedaan hasil belajar siswa antara kelas eksperimen dan kelas kontrol. Hasil penelitian di atas menunjukkan adanya pengaruh model pembelajaran inkuiri berbasis pictorial riddle terhadap hasil belajar, sehingga peneliti mencoba menerapkan model ini terhadap materi fluida dinamis.

Berdasarkan latar belakang di atas, maka penelitian ini akan dilaksanakan dengan tujuan mengetahui 'Pengaruh Model Pembelajaran Inkuiri Berbasis Pictorial Riddle dan Berpikir Kritis terhadap Hasil Belajar Fisika Siswa SMAN 17 Medan'.

\section{METODE PENELITIAN}

Penelitian ini dilaksanakan di SMA Negeri 17 Medan di Jln. Jamin Ginting KM 13,5 pada siswa kelas XI semester 2 Tahun pelajaran 2015/2016. Populasi dalam penelitian ini adalah seluruh siswa kelas XI IPA SMA Negeri 17 Medan yang terdiri dari lima kelas berjumlah 240 orang. Sampel dipilih secara cluster random sampling. Sampel dibagi menjadi satu kelas kontrol dan satu kelas eksperimen.

Penelitian ini melibatkan dua kelas yaitu kelas eksperimen dan kelas kontrol yang diberi perlakuan berbeda. Kelas eksperimen diberi perlakuan yaitu pengajaran dengan menggunakan model pembelajaran inkuiri berbasis pictorial riddle, sedangkan pada kelas kontrol diberi perlakuan yaitu pengajaran dengan menggunakan pembelajaran konvensional. Sebelum perlakuan diberikan, terlebih dahulu dilakukan pretes dan memberikan tes berpikir kritis untuk mengetahui kelompok siswa yang memiliki kemampuan berpikir kritis tinggi dan kemampuan berpikir kritis rendah. 
Desain eksperimen untuk penelitian ini adalah faktorial $2 \times 2$ seperti ditunjukkan Tabel 1.

Tabel 1. Desain Faktorial $2 \times 2$

\begin{tabular}{|c|c|c|c|}
\hline \multirow{2}{*}{$\begin{array}{c}\text { Kemampuan } \\
\text { berpikir } \\
\text { kritis siswa } \\
\text { (A) }\end{array}$} & \multicolumn{2}{|c|}{ Pembelajaran (B) } & \multirow{2}{*}{$\begin{array}{l}\text { Rata- } \\
\text { rata }\end{array}$} \\
\hline & $\begin{array}{c}\text { Inkuiri } \\
\left(\mathrm{B}_{1}\right)\end{array}$ & $\begin{array}{c}\text { Konvensional } \\
\left(\mathrm{B}_{2}\right)\end{array}$ & \\
\hline Tinggi $\left(\mathrm{A}_{1}\right)$ & $\mathrm{A}_{1} \mathrm{~B}_{1}$ & $\mathrm{~A}_{1} \mathrm{~B}_{2}$ & $\mu_{\mathrm{R}}$ \\
\hline Rendah $\left(\mathrm{A}_{2}\right)$ & $\mathrm{A}_{2} \mathrm{~B}_{1}$ & $\mathrm{~A}_{2} \mathrm{~B}_{2}$ & $\mu_{\mathrm{T}}$ \\
\hline Rata-rata & $\mu_{\mathrm{k}}$ & $\mu_{\mathrm{e}}$ & \\
\hline
\end{tabular}

Keterangan :

$\mathrm{A}_{1} \mathrm{~B}_{1}$ : Hasil belajar siswa yang berpikir kritis tinggi dibelajarkan dengan model pembelajaran inkuiri berbasis pictorial riddle.

$\mathrm{A}_{1} \mathrm{~B}_{2} \quad$ : Hasil belajar siswa berpikir kritis tinggi dibelajarkan dengan pembelajaran konvensional.

$\mathrm{A}_{2} \mathrm{~B}_{1}$ : Hasil belajar siswa berpikir kritis rendah dibelajarkan dengan model pembelajaran inkuiri berbasis pictorial riddle.

$\mathrm{A}_{2} \mathrm{~B}_{2}$ : Hasil belajar siswa berpikir kritis rendah dibelajarkan dengan pembelajaran konvensional.

$\mu_{\mathrm{k}} \quad$ : Hasil belajar siswa yang dibelajarkan dengan model pembelajaran inkuiri berbasis pictorial riddle.

$\mu_{\mathrm{e}} \quad$ : Hasil belajar siswa yang dibelajarkan dengan pembelajaran konvensional.

$\mu_{\mathrm{R}} \quad$ : Hasil belajar siswa untuk kelompok dengan kemampuan berpikir kritis tinggi

$\mu_{\mathrm{T}} \quad$ : Hasil belajar siswa untuk kelompok dengan kemampuan berpikir kritis rendah

Berdasarkan variabel penelitian yang disebutkan, terdapat dua cara pengumpulan data penelitian, yaitu: 1) data berpikir kritis siswa dan 2) data hasil belajar fisika siswa. Data berpikir kritis dan hasil belajar fisika siswa diperoleh melalui pertanyaan dari tes yang disediakan.

\section{HASIL PENELITIAN}

Hipotesis penelitian dianalisis menggunakan analisis varians dua jalur.

Kriteria pengujian:

Jika $\mathrm{F}_{\text {Hitung }} \geq \mathrm{F}_{\text {Tabel, }}$ maka tolak $\mathrm{H}_{0}$ berarti berpengaruh.

Berdasarkan perhitungan, ditunjukkan pada tabel hasil analisis varians dua jalur pada Tabel 2.

Tabel 2. Ringkasan Hasil Uji ANAVA

\begin{tabular}{|c|c|c|c|c|c|}
\hline $\begin{array}{c}\text { Sumber } \\
\text { Varians }\end{array}$ & JK & Dk & MK & $F_{\text {hitung }}$ & $F_{\text {tabel }}$ \\
\hline $\begin{array}{c}\text { Model } \\
\text { pembelajaran } \\
\text { (B) }\end{array}$ & 2885 & 1 & 2885 & 43,94 & \\
$\begin{array}{c}\text { Berpikir kritis } \\
(A)\end{array}$ & 6989 & 1 & 6989 & 106,5 & \multirow{2}{*}{3,95} \\
\cline { 1 - 4 } $\begin{array}{c}\text { Model } \\
\text { pembelajaran } \\
\text { dan Berpikir } \\
\text { kritis (BA) }\end{array}$ & 8918 & 1 & 8918 & 135,8 & \\
\cline { 1 - 4 } Dalam (Galat) & 5777 & 88 & 65,65 & - & \\
\hline Total & - & 91 & - & - & \\
\hline
\end{tabular}

\section{Keterangan:}

JK : jumlah kuadrat $\left(\mathrm{JK}_{\mathrm{A}}\right)$ antar kelompok A.

Dk : derajat kebebasan

MK : mean kuadrat 
Berdasarkan Tabel 2 di atas maka hipotesis statistik yang diperoleh adalah:

a. $\quad \mathrm{F}_{\mathrm{B}}$ (hitung) $>\mathrm{F}_{\mathrm{B}}$ (tabel) atau 43,94>3,95 untuk taraf signifikan 0,05, karena harga $F_{B}$ (hitung) lebih besar dari $\mathrm{F}_{\mathrm{B}}$ (tabel), maka $\mathrm{H}_{0}$ ditolak dan $\mathrm{H}_{\mathrm{a}}$ diterima artinya hasil belajar siswa yang dibelajarkan dengan model pembelajaran inkuiri berbasis pictorial riddle lebih tinggi dari pada hasil belajar siswa yang dibelajarkan dengan pembelajaran konvensional, berarti ) terdapat perbedaan hasil belajar fisika siswa yang mengunakan model pembelajaran inkuiri berbasis pictorial riddle dengan pembelajaran konvensional pada materi pokok fluida dinamis di kelas XI Semester II SMA Negeri 17 Medan T.P. 2015/2016.

b. $\quad \mathrm{F}_{\mathrm{A}}$ (hitung) $>\mathrm{F}_{\mathrm{A}}$ (tabel) atau $106,5>3,95$ untuk taraf signifikan 0,05 , karena harga $\mathrm{F}_{\mathrm{A}}$ (hitung) lebih besar dari $\mathrm{F}_{\mathrm{A}}$ (tabel), maka $\mathrm{H}_{0}$ ditolak dan $\mathrm{H}_{\mathrm{a}}$ diterima artinya hasil belajar siswa untuk kelompok dengan kemampuan berpikir kritis tinggi lebih tinggi dari pada hasil belajar siswa untuk kelompok dengan kemampuan berpikir kritis rendah berarti terdapat perbedaan hasil belajar fisika siswa yang berpikir kritis tinggi dengan berpikir kritis rendah pada materi pokok fluida dinamis di kelas XI Semester II SMA Negeri 17 Medan T.P. 2015/2016.

c. $\mathrm{F}_{\mathrm{BA}}$ (hitung) $>\mathrm{F}_{\mathrm{BA}}$ (tabel) atau $135,8>3,95$ untuk taraf signifikan 0,05, karena harga $\mathrm{F}_{\mathrm{BA}}$ (hitung) lebih besar dari $\mathrm{F}_{\mathrm{BA}}$ (tabel), maka $\mathrm{H}_{0}$ ditolak dan $\mathrm{H}_{\mathrm{a}}$ diterima artinya terdapat interaksi antara model pembelajaran inkuiri berbasis pictorial riddle dan berpikir kritis terhadap hasil belajar fisika siswa pada materi pokok fluida dinamis di kelas XI Semester II SMA Negeri 17 Medan T.P. 2015/2016

\section{PEMBAHASAN}

Tujuan umum model pembelajaran inkuiri berbasis pictorial riddle adalah membantu siswa untuk menggunakan proses berpikir secara kritis dan analisis dalam mencari dan menemukan sendiri jawaban dari suatu masalah yang dipertanyakan (Joice, dkk., 2011). Model pembelajaran inkuiri berbasis pictorial riddle dirancang untuk membawa siswa ke dalam proses ilmiah melalui gambar yang memiliki teka-teki (riddle) yang dapat memadatkan proses ilmiah tersebut ke dalam periode waktu yang singkat. Pengaruhnya adalah bahwa model pembelajaran inkuiri berbasis pictorial riddle akan meningkatkan ilmu pengetahuan, produktivitas, dan keterampilan-keterampilan dalam memperoleh dan menganalisis informasi, tetapi penyelidikan ini seefisisen model pengulangan dan pengajaran yang dilakukan dengan pengalaman-pengalaman dalam menganalisis gambar. Model pembelajaran inkuiri berbasis pictorial riddle lebih efektif dibandingkan dengan pembelajaran konvensional.

Hasil yang diperoleh dari penelitian ini menunjukkan terdapat perbedaan hasil belajar siswa pada 
kelas eksperimen yang menggunakan model pembelajaran inkuiri berbasis pictorial riddle dengan kelas kontrol yang menggunakan pembelajaran konvensional. Hal ini diperoleh dengan diberikannya perlakuan yang maksimal sesuai tujuan orang yang berinkuiri. Nilai rata-rata hasil belajar siswa di kelas eksperimen eksperimen sebesar 71,47 dan kelas kontrol sebesar 60,33. Dapat disimpulkan bahwa hasil belajar siswa lebih baik jika diajarkan dengan menggunakan model pembelajaran inkuiri berbasis pictorial riddle. Berarti model pembelajaran inkuiri berbasis pictorial riddle lebih baik dari pembelajaran konvensional. Senada dengan hasil penelitian Kristianingsih (2010) dengan kesimpulan bahwa model pembelajaran inkuiri dengan metode pictorial riddle dapat meningkatkan hasil belajar siswa. Temuan penelitian ini senada dengan hasil penelitian terdahulu Sirait (2012) menyatakan terdapat perbedaan yang signifikan hasil belajar siswa yang menggunakan model pembelajaran inkuiri dengan pembelajaran konvensional.

Berpikir kritis merupakan pola berpikir tentang subjek, isi atau masalah yang mana pemikir mengembangkan kualitas berpikirnya secara ahli menggunakan struktur yang melekat dalam pikirian dan menerapkan struktur tersebut pada standar intelektual. Rata-rata kemampuan berpikir kritis rendah pada kelas eksperimen dan kelas kontrol secara berturut-turut adalah 22,11 dan 24,17. Rata-rata kemampuan berpikir kritis tinggi pada kelas eksperimen dan kelas kontrol adalah 20,79 dan 21,3. Hasil belajar siswa untuk kemapuan berpikir kritis rendah pada kelas eksperimen dan kelas kontrol secara berturut-turut adalah 61,54 dan 54,44. Rata-rata hasil belajar siswa untuk kemampuan berpikir kritis tinggi pada kelas eksperimen dan kelas kontrol secara berturut-turut adalah 79,8 dan 68,68 .

Berdasarkan pada pengujian maka hasil belajar siswa berdasarkan kemampuan berpikir kritis rendah memiliki rata-rata sebesar 57,99 dan sementara hasil belajar siswa berdasarkan kemampuan berpikir kritis tinggi memiliki rata-rata sebesar 74,24. Dari data tersebut dapat dilihat bahwa hasil belajar siswa dengan kemampuan berpikir kritis tinggi lebih baik dibanding dengan hasil belajar siswa dengan hasil belajar siswa dengan kemampuan berpikir kritis rendah.

Penelitian ini menunjukkan bahwa siswa yang memiliki kemampuan berpikir kritis tinggi memiliki nilai hasil belajar siswa yang tinggi dan sebaliknya siswa yang memiliki kemampuan berpikir kritis rendah memiliki hasil belajar siswa yang rendah juga. Dengan kata lain, apabila siswa pada dasarnya memiliki kemampuan berpikir kritis tinggi jika diajarkan dengan model pembelajaran inkuiri berbasis pictorial riddle maupun pembelajaran konvensional akan menghasilkan haisl belajar siswa yang tinggi. Guilford dalam (Gulo, 2011) menyatakan bahwa dalam pengembangan hasil belajar inkuiri juga termasuk pemberdayaan kemampuan berpikir kritis. Dalam memberdayakan hasil belajar inkuiri dapat dilakukan bersama pemberdayaan kemampuan berpikir kritis. Siswa yang memiliki kemampuan berpikir kritis rendah cenderung memperoleh nilai yang kurang memuaskan. Sebaliknya siswa yang memiliki kemampuan berpikir 
tinggi akan selalu berusaha untuk mencapai prestasi sesuai standar yang ditetapkan.

Hasil yang diperoleh tersebut senada dengan peneliti terdahulu, Mahmudah (2014) yang menyatakan bahwa ada pengaruh kemampuan berpikir kritis tinggi dan rendah terhadap hasil belajar siswa. Kemampuan berpikir kritis berpengaruh positif terhadap hasil belajar siswa dan memberikan arahan yang tepat dalam berpikir, dan membantu dalam menentukan keterkaitan sesuatu yang lainnya dengan akurat.

Hasil belajar siswa akan dicapai dengan baik oleh siswa ditentukan oleh aktivitas guru, siswa dan kegiatan proses belajar mengajar di kelas. Guilford dalam (Gulo, 2011) menyatakan untuk merangsang kegiatan berpikir peserta didik, maka perlu diketahui apa yang dia ketahui dan bagaimana cara ia berpikir. Kemampuan berpikir kritis mempunyai pengaruh pada keberhasilan pelaksanan model pembelajaran inkuiri. Inkuiri berbasis pictorial riddle bertolak pada kepercayaan bahwa agar seseorang menjadi mandiri, dituntut model yang dapat memberi kemudahan pada pembelajar untuk melibatkan diri induktif dalam menemukan pengetahuan dan berpusat pada keaktifan pembelajar.

Hasil perhitungan untuk melihat interaksi model pembelajaran inkuiri berbasis pictorial riddle dan kemampuan berpikir kritis terhadap hasil belajar siswa diperoleh nilai $F_{\text {hitung }}$ lebih besar dari pada $\mathrm{F}_{\text {tabel. }}$. Maka dalam penelitian ini terdapat ineraksi antara model pembelajaran inkuiri berbasis pictorial riddle dan kemampuan berpikir kritis dalam mempengaruhi hasil belajar siswa. Penelitian ini sejalan dengan peneliti Mahmudah (2014) yang menyatakan ada interaksi antara metode pictorial riddle dengan kemampuan berpikir kritis terhadap prestasi belajar kognitif dan afektif.

Penelitian ini menunjukkan adanya interaksi antara model pembelajaran inkuiri berbasi pictorial riddle dan kemampuan berpikir kritis saling mempengaruhi dalam meningkatkan hasil belajar siswa yang artinya model pembelajaran inkuiri berbasis pictorial riddle berpengaruh optimal untuk meningkatkan hasil belajar siswa jika diterapkan pada siswa yang memiliki kemampuan berpikir kritis tinggi. Pada saat proses pembelajaran yang diajarkan dengan menggunakan model pembelajaran inkuiri berbasis pictorial riddle, siswa yang memiliki kemampuan berpikir kritis tinggi lebih aktif belajar dibandingkan siswa yang memiliki kemampuan berpikir kritis rendah. Mereka memiliki sikap yang mampu mengkaji masalah dengan penuh pertimbangan, memiliki pengetahuan mengenai metode riddle, dan keahlian dalam menerapkan metode riddle tersebut begitu juga pada pembelajaran konvensional.

\section{KESIMPULAN}

Berdasarkan hasil penelitian, analisis data dan uji hipotesis, dapat disimpulkan bahwa:
1. Terdapat perbedaan hasil belajar fisika siswa yang mengunakan model pembelajaran inkuiri berbasis pictorial riddle dengan pembelajaran konvensional. 
2. Terdapat perbedaan hasil belajar fisika siswa yang berpikir kritis tinggi dengan berpikir kritis rendah.

3. Terdapat interaksi antara model pembelajaran inkuiri berbasis pictorial riddle dan berpikir kritis terhadap hasil belajar fisika siswa.

\section{SARAN}

Berdasarkan hasildan kesimpulan dalam penelitian ini, peneliti menyarankan kepada peneliti selanjutnya lebih memaksimalkan waktu pada fase pembelajaran "mengolah, merumuskan penjelasan yang jelas" karena pada fase sebelumnya "mengumpulkan data eksperimentasi" membutuhkan waktu yang banyak dan konsentrasi peserta didik.

\section{DAFTAR PUSTAKA}

Fisher, (2009), Berpikir Kritis: Sebuah Pengantar, Erlangga, Jakarta

Giancoli, (2014), Fisika: Prinsip dan Aplikasi, Erlangga, Jakarta

Gulo, W., (2011), Strategi Belajar Mengajar, Gramedia Widiasarana Indonesia, Jakarta

Hamruni, (2012), Strategi Pembelajaran, Insan Madani, Yogyakarta

Joyce, B., (2011), Models Of Teaching, Pustaka Pelajar, Jakarta

Kristianingsih, dkk., (2010), Peningkatan Hasil Belajar Siswa Melalui Model
Pembelajaran Inkuiri dengan Metode Pictorial Riddle pada Pokok Bahasan Alat- Alat Optik di SMP, Jurnal Pendidikan Fisika Indonesia, 6: 10-13

Mahmudah, dkk., (2014), Pembelajaran Fisika Menggunakan Metode Pictorial Riddle dan Problem Solving Ditinjau dari Kemampuan Berpikir Kritis dan Kemampuan Analisis, Jurnal Inkuiri, 3: 48-59

Ngalimun, (2012), Strategi Pembelajaran Pendidikan, Bumi Aksara, Jakarta

Rangkuti, (2010), Pengaruh Model Pembelajaran Inquiry Berbasis Pictorial Riddle terhadap Hasil Belajar Siswa pada Materi Pokok Gejala Gelombang di Kelas XII Semester I SMA N 4 Binjai T.P 2010/2011, Skripsi, FMIPA, Unimed, Medan

Riduan, (2009), Dasar-Dasar Statistika, Alfabeta, Bandung

Sanjaya, W., (2010), Strategi Pembelajaran Berorientasi Standar Proses Pendidikan, Kencana Prenada Media Group, Jakarta

Sirait, (2012), Pengaruh Model Pembelajaran Inquiry Training terhadap Hasil Belajar Siswa pada Materi Pokok Usaha dan Energi Kelas VIII MTS N 3 Medan, Jurnal Pendidikan Fisika Program Pascasarjana Universitas Negeri Medan, 1(1) 